\title{
PENINGKATAN PRESTASI BELAJAR AL-QUR'AN HADITS MELALUI METODE MIND MAPPING PADA SISWA KELAS VII A MTs NEGERI 4 BANTUL TAHUN PELAJARAN 2019-2020
}

\author{
Oleh. \\ Mafrudah \\ Madrasah Tsanawiyah Negeri 4 Bantul \\ e-mail:mafyoke@gmail.com
}

\begin{abstract}
This study aims to find out how to improve students' motivation and learning outcomes through the Mind Mapping method in learning the Qur'anic Hadith. This research is a class action research (Classroom Action Resarch) The subject of this study was students of class VII A MTs Negeri 4 Bantul in the academic year 2019-2020. The results of this study indicate a significant increase in motivation and learning outcomes. The percentage of students' motivation in cycle 1 of meeting 1 was $66.66 \%$, cycle 2 of meeting 2 rose to $93.33 \%$. Percentage of student learning outcomes in the $16.66 \%$ pre cycle complete. In cycle 1 it increased to $86.66 \%$ and in cycle 2 it increased again to $96.66 \%$ which was complete. The application of the Mind Mapping method in learning the Qur'an the Hadith can increase motivation and learning outcomes by making modifications in terms of; the use of attractive methods and media, grouping and seating arrangements, and effective classroom management strategies.
\end{abstract}

Keywords: Mind Mapping, motivation and learning outcomes

\begin{abstract}
Abstrak
Penelitian ini bertujuan untuk mengetahui bagaimana cara meningkatkan motivasi dan hasil belajar siswa melalui metode Mind Mapping dalam pembelajaran Al Qur'an Hadis. Penelitian ini merupakan penelitian tindakan kelas (Classroom Action Resarch). Subyek penelitian ini adalah siswa kelas VII A MTs Negeri 4 Bantul tahun pelajaran 2019-2020. Hasil penelitian ini menunjukkan adanya peningkatan motivasi dan hasil belajar secara signifikan. Prosentase motivasi belajar siswa pada siklus 1 pertemuan 1 sebesar $66.66 \%$, siklus 2 pertemuan 2 naik menjadi 93,33\%. Prosentase hasil belajar siswa pada pra siklus sebesar $16,66 \%$ yang tuntas. Pada siklus 1 naik menjadi $86.66 \%$ dan pada siklus 2 mengalami kenaikan lagi menjadi 96,66\% yang tuntas. Penerapan metode Mind Mapping dalam pembelajaran Al Qur'an Hadis dapat meningkatkan motivasi dan hasil belajar dengan melakukan modifikasi dalam hal; penggunaan metode dan media yang menarik, pengaturan pengelompokan siswa dan tempat duduk, serta strategi pengelolaan kelas yang efektif.
\end{abstract}


Kata kunci: Mind Mapping, motivasi dan hasil belajar

\section{A. PENDAHULUAN}

Melalui pendidikan diharapkan mampu membangun akhlak dan kepribadian generasi muda Indonesia sebagai penerus kepemimpinan di masa yang akan datang. Pendidikan mempunyai peran yang penting berkaitan dengan pemeliharaan dan perbaikan kehidupan suatu masyarakat dan bangsa. Undang-undang No. 20 tahun 2003 tentang Sistem Pendidikan Nasional menyebutkan bahwa pendidikan sebagai usaha sadar dan terencana untuk mewujudkan suasana belajar dan proses pembelajaran agar peserta didik secara aktif mengembangkan potensi dirinya untuk memiliki kekuatan spiritual keagamaan, pengendalian diri, kepribadian, kecerdasan, akhlak mulia, serta ketrampilan yang diperlukan dirinya, masyarakat, bangsa dan negara.

Dalam pembelajaran terdapat tiga komponen utama yang saling berpengaruh dalam proses belajar mengajar. Ketiga komponen tersebut adalah (1) kondisi pembelajaran (2) metode pembelajaran, dan (3) hasil pembelajaran. Terkait tentang ketiga komponen tersebut, maka guru harus mampu memadukan dan mengembangkannya, supaya kegiatan pembelajaran dapat berjalan sesuai dengan yang diharapkan, tercapai tujuan pembelajaran, dan menuai hasil yang maksimal. Oleh karena itu, dengan bekal kemampuan dan ketrampilan yang dimiliki guru diharapkan mampu menjadikan pembelajaran lebih menarik dan menyenangkan, sehingga memperoleh hasil belajar yang optimal. Untuk mencapai kualitas pembelajaran tersebut, keterampilan guru menggunakan metode dalam proses pembelajaran sangatlah penting dan harus ditingkatkan. Proses pembelajaran harus menggunakan metode yang tepat sesuai dengan visi misi madrasah masing-masing.

Metode pembelajaran Al Qur'an Hadis di kelas selama ini menggunakan metode ceramah yang bersifat one way communication. Dalam pembelajaran konvensional, menganggap guru adalah satusatunya sumber belajar yang dianggap serba tahu. Jika penerapan metode pembelajaran untuk mata pelajaran Al-Quran Hadis hanya menggunakan metode ceramah sebagai metode utama, maka proses pembelajaran akan terasa membosankan bagi peserta didik karena bersifat monoton. Kondisi ini diduga akan sangat mempengaruhi keaktifan dan prestasi belajar peserta didik di dalam kelas. Metode ceramah sebagai metode utama bukan berarti tidak cocok untuk digunakan tetapi penggunaan metode tersebut yang mendominasi menyebabkan peserta didik merasa bosan, jenuh dan tidak dapat berperan aktif serta tidak bisa belajar mandiri, sehingga mengakibatkan prestasi belajar peserta didik menjadi rendah. Pembelajaran Al Qur'an Hadis meliputi membaca, menulis, menghafal 
dan memahami penjelasan/isi kandungan ayat. Dalam memahami penjelasan dan maksud dari ayat $\mathrm{Al}$ Qur'an, peserta didik sering kali merasa kesulitan karena mereka kurang terbiasa membaca. Membaca butuh konsentrasi dan penghayatan, ketika disuruh membaca, kebanyakan peserta didik kurang bisa memahami maksud dari apa yang dibaca karena kurang konsentrasi terhadap apa yang dibaca. Ditambah dengan kebiasaan guru yang hanya sekedar ceramah dalam penyampaian materi, anak disuruh duduk tenang dan mendengarkan, hal ini membuat peserta didik semakin bosan dan pembelajaran menjadi kurang menarik, sehingga hasilnya tidak sesuai KKM.

Beberapa penyebab nilai tidak mencapai KKM adalah kurangnya motivasi peserta didik dalam belajar, kurang suka membaca dan kurang konsentrasi sehingga kurang bisa memahami maksud dari tulisan/bacaan. Seharusnya nilai Qur'an Hadis bisa mencapai KKM bahkan bisa melampauinya kalau mereka mempunyai motivasi dan semangat untuk belajar. Hal ini akan terjadi kalau guru tepat dalam memilih metode.

Berdasarkan latar belakang permasalahan seperti tersebut di atas penulis merasa perlu ada perubahan metode mengajar, tidak sekedar ceramah dan mencatat seperti biasanya tapi perlu menggunakan metode peta konsep (mind mapping).

\section{B. METODE PENELITIAN}

Penelitian Tindakan Kelas ini dilakukan di kelas VIIA semester gasal MTs Negeri 4 Bantul pada tahun pelajaran 2019-2020, dari bulan Juli sampai Oktober 2019. Kelas VIIA MTs Negeri 4 Bantul terdiri dari 30 peserta didik dengan jumlah peserta didik putra 14 dan peserta didik putri 16. Sebagian besar peserta didik berasal dari daerah yang tidak jauh dari lokasi madrasah, walaupun ada beberapa peserta didik yang berdomisili jauh dari madrasah. Mereka berasal dari sekitar kecamatan Sewon, Bantul, Bambanglipura, Pandak, Kretek, Srandakan, di wilayah Kabupaten Bantul. Keadaan ekonomi orang tua/wali peserta didik rata-rata ekonomi menengah ke bawah dengan mata pencaharian utama adalah buruh baik buruh sawah, buruh pabrik, buruh rumah tangga, buruh bangunan dan tukang becak. Diantara orang tua/wali peserta didik juga ada yang tani, berdagang di pasar, dan PNS.

Secara garis besar tingkat kemampuan peserta didik MTs Negeri 4 Bantul sangat heterogen karena proses seleksi peserta didik melalui beberapa gelombang. Gelombang pertama dibuka sebelum peserta didik SD/MI mengikuti ujian, adalah peserta didik yang benar-benar berminat ingin sekolah di MTs Negeri 4 Bantul tanpa mempertimbangkan perolehan NEM . Untuk gelombang selanjutnya adalah mayoritas peserta didik yang tidak diterima di SMP Negeri sekitar. Walaupun ada juga yang NEM nya tinggi dan memang dari awal berkeinginan sekolah di MTsN 4 Bantul. Sehingga kondisi input peserta didik sangat heterogen, ada yang NEM nya tinggi ada juga yang sangat rendah. Hal ini merupakan salah satu faktor yang menentukan keberhasilan kegiatan pembelajaran Al Qur'an Hadis, apalagi sebagian besar peserta didik yang diterima adalah dari 
lulusan SD yang tidak ada pelajaran $\mathrm{Al}$ Qur'an Hadis.

Berdasarkan evaluasi awal peserta didik MTs Negeri 4 Bantul sebelum diadakan penelitian ini adalah nilai rata-rata hasil belajar peserta didik 6,3 dengan tingkat keaktifan peserta didik 50\%. Penelitian ini dikatakan berhasil apabila : rata-rata hasil belajar peserta didik pada materi Al Qur'an Hadis 71 (sesuai KKM); 75\% peserta didik mendapat nilai minimal 71 ; peserta didik tuntas mencapai $75 \%$; tingkat keaktifan peserta didik rata-rata $60 \%$.

\section{KAJIAN TEORI}

Metode mind mapping adalah cara mencatat yang kreatif, efektif dan secara harfiah akan memetakan pikiran-pikiran. Selain itu mind map juga sangat sederhan. Mind mapping menggunakan kemampuan otak akan pengenalan visual untuk mendapat hasil yang sebesar-besarnya. Dengan kombinasi warna, gambar, dan cabangcabang melengkung, mind map lebih merangsang secara visual dari pada metode pencatatan tradisional, yang cenderung linear dan satu warna, ini akan sangat memudahkan peserta didik mengingat informasi. ${ }^{1}$

Oleh karena itu peneliti mengangkat judul "Metode Mind Mapping Dapat Meningkatkan Prestasi Belajar Al Qur'an Hadis Pada Peserta Didik Kelas VII A Mts Negeri 4 Bantul Tahun Pelajaran 2019-2020".

Sebagai penemu dari metode ini, Buzan $^{2} \quad$ (2008:4) mengungkapkan

${ }^{1}$ Tony Buzan, Buku Pintar Mind Map, (Jakarta: Gramedia Pustaka Utama, 2006) hal.4

${ }^{2}$ Ibid. hal 4
"Mind mapping adalah cara mengembangkan kegiatan berpikir ke segala arah, menangkap berbagai pikiran dalam berbagai sudut. Mind mapping mengembangkan cara berpikir divergen dan kreatif . Mind mapping juga disebut juga dengan peta konsep merupakan alat berpikir organisasional yang sangat hebat, ini juga merupakan cara termudah untuk menempatkan informasi dalam otak dan mengambil informasi itu saat dibutuhkan. Mind mapping dapat membantu dalam berbagai hal seperti merencanakan, berkomunikasi, menjadi lebih kreatif, menyelesaikan masalah, memusatkan perhatian, menyusun dan menjelaskan pikiran, mengingat dengan baik, belajar lebih cepat dan efisien serta melatih gambar keseluruhan".

Pemetaan pikiran menurut Aris Shoimin $^{3}$ adalah teknik pemanfaatan seluruh otak dengan menggunakan citra visual dan prasarana grafis lainnya untuk membentuk kesan. Otak sering kali mengingat informasi dalam bentuk gambar, simbol, suara, bentuk bentuk dan perasaan. Peta pikiran menggunkaan pengingat-pengingat visual dan sensorik ini dalam suatu pola dari ide-ide yang berkaitan seperti peta jalan yang digunakan untuk belajar, mengorganisasikan, dan merencanakan. Peta ini dapat membangkitkan ide-ide orisinil dan memicu ingatan yang mudah. Ini jauh lebih mudah daripada metode pencatatan tradisional karena mengaktifkan kedua belahan otak. Cara

3 Aris Shoimin, 68 Model Pembelajaran Inovati dalam Kurikulum 2013, (Yogyakarta:Ar-Ruzz Media, 2014) hal. 105106 
ini juga menenangkan, menyenangkan, dan kreatif. Dalam mind map, sistem kerja otak diatur secara alami. Oleh karena itu, dalam proses kerjanya pun sesuai dengan kealamian dari cara berpikir manusia. Mind map membuat otak manusia tereksplorasi dengan baik dan bekerja sesuai fungsinya. Maka dengan menggunakan sistem mind map, kedua sistem otak bekerja sejalan. Artinya, dalam melakukan kerjanya, otak tidak berat sebelah sehingga bisa tereksplorasi dengan baik. Mind map sangat mudah dipraktikkan dalam setiap kegiatan sehari-hari.

Suyatno menyebutkan bahwa pembelajaran Mind mapping sangat cocok untuk mereview pengetahuan awal peserta didik. Disamping itu, Buzan) mengungkapkan bahwa simbol dan gambar seringkali lebih berdaya untuk mengungkapkan pikiran maupun mengingat suatu hal. Karena menurutnya "Otak memiliki kemampuan alami untuk pengenalan visual, bahkan sebenarnya pengenalan Mind Mapping yang sempurna". Oleh karena itu, simbol-simbol dan ilustrasiilustrasi dapat ditambahkan pada Mind mapping yang dibuat untuk menambatkan ingatan yang lebih baik. Selain itu Mind mapping yang baik dibuat dengan mengkombinasikan beberapa warna sehingga terkesan berwarna-warni dan tidak monoton.

Berdasarkan pendapat di atas, dapat disimpulkan bahwa Mind mapping adalah sebuah diagram yang mempresentasikan kata-kata, ide (pikiran), tugas-tugas atau hal lain untuk memudahkan kita dalam mengingat banyak informasi. Peta pikiran tersebut, peta informasi yang panjang dapat dibuat menjadi diagram warna-warni, sangat teratur, dan mudah diingat, yang bekerja selaras dengan cara kerja alami otak dalam berbagai hal.

\section{Mind mapping}

Mind mapping/peta pikiran memberikan banyak manfaat. Peta pikiran, memberikan pandangan menyeluruh pada setiap aspek permasalahan dan memberikan sudut pandang pada area yang luas, memungkinkan kita merencanakan rute atau membuat pilihan-pilihan dan mengetahui kemana kita akan pergi dan dimana kita berada. Keuntungan lain yaitu mengumpulkan sejumlah besar data di suatu tempat, mendorong pemecahan masalah dengan membiarkan kita melihat jalan-jalan terobosan kreatif baru, merupakan sesuatu yang menyenangkan untuk dipandang, dibaca, direnungkan dan diingat. Untuk peserta didik, peta pikiran memiliki manfaat, yaitu: membantu dalam mengingat, mendapatkan ide, menghemat waktu, berkonsentrasi, mendapatkan nilai yang lebih bagus, mengatur pikiran dan hobi, media bermain, bersenang-senang dalam menuangkan imajinasi yang tentunya memunculkan kreativitas.

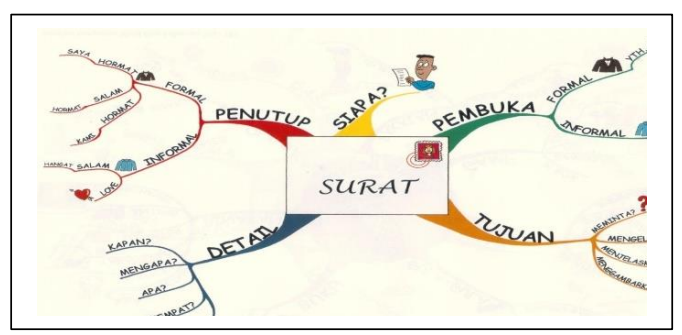

Gambar 1. Mind Mapping

\section{Prestasi Belajar}

Prestasi belajar adalah sebuah kalimat yang terdiri dari dua kata, yakni prestasi dan belajar. Untuk memahami lebih jauh tentang 
pengertian prestasi belajar, peneliti menjabarkan makna dari kedua kata tersebut. Menurut Kamus Umum Bahasa Indonesia, pengertian prestasi adalah hasil yang telah dicapai (dari yang telah diakukan, dikerjakan, dan sebagainya). ${ }^{4}$

Sedangkan menurut Saiful Bahri Djamarah dalam bukunya Prestasi Belajar dan Kompetensi Guru, bahwa prestasi adalah apa yang telah dapat diciptakan, hasil pekerjaan, hasil yang menyenangkan hati yang diperoleh dengan jalan keuletan kerja. Dalam buku yang sama Nasrun Harahap, berpendapat bahwa prestasi adalah penilaian pendidikan tentang perkembangan dan kemajuan peserta didik berkenaan dengan penguasaan bahan pelajaran yang disajikan kepada peserta didik.

Dari pengertian di atas dapat diambil kesimpulan bahwa prestasi adalah hasil dari suatu kegiatan seseorang atau kelompok yang telah dikerjakan, diciptakan dan menyenangkan hati yang diperoleh dengan jalan bekerja.

\section{Ruang Lingkup Mata Pelajaran Al Qur'an hadis}

Ruang lingkup mata pelajaran Al-Qur'an-Hadis di Madrasah Tsanawiyah meliputi: membaca dan menulis yang merupakan unsur penerapan ilmu tajwid; menerjemahkan makna (tafsiran) yang merupakan pemahaman, interpretasi ayat, dan hadis dalam memperkaya khazanah intelektual; menerapkan isi kandungan ayat/hadis yang merupakan unsur

4 Poerwadarminta, W.J.S, Kamus Umum Bahasa Indonesia (Jakarta, Balai Pustaka, 1991) hal. 787 pengamalan nyata dalam kehidupan sehari-hari. (KMA, 2014)

\section{PEMBAHASAN}

Rencana penelitian ini dilakukan dalam 2 kali pertemuan, pertemuan pertama peneliti melakukan siklus I dan pada pertemuan kedua peneliti melakukan siklus II. Pada kedua siklus peneliti menerapkan metode Mind Mapping untuk menyampaikan materi Tauhid QS. Al Fatihah, QS. An Naas, QS. Al Falaq, QS. Al Ikhlas.

\section{Siklus I Pertemuan 1}

Untuk merencanakan proses pembelajaran agar meningkatkan motivasi dan hasil pembelajaran perlu dilakukan hal-hal berikut: berdiskusi dengan kolaborator mengenai metode pembelajaran yang akan digunakan untuk meningkatkan motivasi dan hasil belajar Al Qur'an Hadis pada materi tauhid QS. Al Fatihah dan QS. An Naas. Metode yang digunakan dalam penelitian ini adalah Ming Mapping, membuat RPP dan alat pembelajaran sesuai dengan metode Mind Mappin, mempersiapkan lembar observasi atau lembar pengamatan. Lembar pengamatan dipersiapkan untuk mengamati motivasi siswa dan guru, saat melakukan proses pembelajaran, merancang desain kelas untuk menghadirkan suasana belajar yang nyaman, merancang tes hasil belajar diakhir pembelajaran. Tes digunakan sebagai alat pengukur hasil belajar siswa.

Materi yang diajarkan pada siklus I pertemuan 1 adalah tentang tauhid QS. Al Fatihah, QS. An Naas. 
Pelaksanaan pembelajaran berdurasi waktu 2X40 menit. Langkah-langkah pembelajaran yang dilakukan adalah sebagai berikut: Kegiatan awal : guru mengucapkan salam dan berdoa bersama; guru memeriksa kehadiran, kerapian berpakaian, posisi tempat duduk disesuaikan dengan kegiatan pembelajaran; guru menyampaikan tujuan pembelajaran; guru memotivasi peserta didik tentang pentingnya tauhid; guru bertanya tentang pelajaran yang telah lalu (fungsi Al Quran); guru menyampaikan Kompetensi Dasar terkait dengan materi yang akan disampaikan.

Kegiatan Inti : peserta didik mengamati gambar dalam buku paket tentang aktifitas orang yang menyembah dan memuji benda yang tidak mempunyai kekuatan apapun dan alam raya; peserta didik membaca materi tauhid QS. Al Fatihah dan QS. An Naas; peserta didik mengamati penjelasan guru melalui gambar/tayangan mind mapping tentang materi tauhid QS. Al Fatihah; guru membagi peserta didik menjadi 6 kelompok dengan cara berhitung; peserta didik mempersiapkan media/alat bantu pembelajaran (kertas manila, kertas origami/asturo, gunting, spidol, lem); peserta didik mengemukakan hasil pengamatannya dengan membuat mind mapping secara kelompok; guru memberikan penjelasan tambahan tentang cara membuat mind mapping sesuai dengan materi; peserta didik mendiskusikan dan merumuskan hasil pencarian informasi tentang tauhid QS. Al Fatihah dan QS. An Naas dengan membuat mind mapping secara kelompok, dengan bahan-bahan yang sudah disiapkan terlebih dulu; peserta didik saling mengkomunikasikan dan memberi masukan sambil membuat mind mapping dalam kelompoknya masing-masing.

Kegiatan Penutup : peserta didik bersama guru membuat kesimpulan tentang materi pembelajaran yang telah dilakukan; menugaskan peserta didik untuk pertemuan berikutnya, belajar menyempurnakan mind mapping yang telah dibuat oleh kelompoknya; peserta didik diminta melakukan refleksi dengan menjawab pertanyaan pertanyaan yang diajukan guru; peserta didik menjawab soal-soal post tes; menutup pelajaran dengan berdoa membaca hamdalah bersama..

Pada siklus I pertemuan 1 guru telah menerapkan metode Mind Mapping. Secara umum selama pembelajaran peserta didik menunjukkan sikap yang cukup baik, mulai berkembang kerjasamanya, keaktifannya, kepeduliaan dan juga kesantunannya. Tapi dalam hal inisiatif, peserta didik baru memperlihatkannya belum berkembang dengan baik.

Peserta didik melaksanakan pembelajaran sudah sesuai dengan sintaks metode mind mapping mulai dari mendengarkan penjelasan guru, mengambil posisi sesuai dengan kelompok masing-masing, berbagi tugas dalam kelompok, menyiapkan bahan dan peralatan masing-masing, saling diskusi menentukan bentuk mind mapping, sampai praktek membuat mind mapping.

Sehubungan dengan motivasi belajar, secara keseluruhan peserta didik bersemangat. Dalam hal perhatian dan menjawab pertanyaan 
mereka sudah cukup baik memperhatikan penjelasan dan menjawab pertanyaan guru. Sementara dalam hal inisiatif mereka masih perlu rangsangan dan contoh. Apabila diprosentasekan dapat dilihat pada tabel berikut :

\section{Tabel 1.}

\section{Motivasi peserta didik siklus I}

\begin{tabular}{|r|l|c|c|}
\hline No & $\begin{array}{l}\text { Predikat } \\
\text { motivasi }\end{array}$ & Jumlah & Prosentase \\
\hline 1 & Sangat baik & 0 & $00,00 \%$ \\
\hline 2 & Baik & 20 & $66,66 \%$ \\
\hline 3 & Sedang & 10 & $33,33 \%$ \\
\hline 4 & Kurang & 0 & $0.00 \%$ \\
\hline 5 & Sangat kurang & 0 & $0.00 \%$ \\
\hline
\end{tabular}

Peserta didik mengikuti pembelajaran dengan gembira, aktif dan juga tepat waktu sesuai dengan instruksi yang ada. Hasil produk mind mapping tiap kelompok sangat beragam dilihat dari bentuk, warna dan konten materinya. Instrumen yang dinilai adalah ketepatan konten/materi, kreatifitas, dan orisinilitas. Secara keseluruhan konten materi yang ditampilkan sudah tepat dan benar.

Hasil belajar siswa pada siklus I diperoleh dari post tes materi tauhid QS. Al Fatihah dan QS. An Naas. Hasil belajar yang dimiliki siswa setelah selesai pembelajaran sudah ada peningkatan dari pra siklus. Sebanyak $86,66 \%$ peserta didik memiliki nilai melampaui KKM. Sebanyak 13,33\% siswa memperoleh nilai di bawah KKM. Sebanyak 30 peserta didik yang mengikuti pembelajaran ada 26 siswa yang memperoleh nilai mencapai KKM. Sebanyak 4 peserta didik memperoleh nilai di bawah KKM. Apabila diperosentasekan dapat dilihat pada tabel berikut :
Tabel 2.

\section{Perolehan nilai post tes siklus I}

\begin{tabular}{|l|c|c|c|l|}
\hline No & Kriteria & Jml & $\%$ & Tingkat \\
\hline 1 & KKM $<$ & 4 & $13,33 \%$ & $\begin{array}{l}\text { Di } \\
\text { bawah } \\
\text { KKM }\end{array}$ \\
\hline 2 & KKM $>$ & 26 & $86,66 \%$ & $\begin{array}{l}\text { Di atas } \\
\text { KKM }\end{array}$ \\
\hline
\end{tabular}

Refleksi dilakukan dalam 4 aspek yakni aspek proses pembelajaran, penerapan metode PRP, motivasi belajar dan hasil belajar. Berdasarkan hasil diskusi dengan kolaborator disimpulkan beberapa hal untuk perbaikan pada pertemuan berikutnya. Kesimpulan refleksi siklus 1 antara lain : kegiatan Pendahuluan sudah bagus; kegiatan Inti secara keseluruhan sudah baik berjalan sesuai perencanaan.

\section{Siklus II pertemuan 2}

\section{Dilaksanakan}

untuk menyampaikan materi tauhid QS. Al Falaq dan Al Ikhlas. Pelaksanaan pembelajaran pada siklus II ini dilaksanakan dengan tahapan tahapan. Setelah melaksanakan pertemuan pada siklus I dilanjutkan dengan refleksi dengan kolaborator. Hasil refleksi dengan kolaborator dimanfaatkan untuk merencanakan pertemuan ke 2 siklus II. Adapun perencanaan yang dilakukan:

Langkah pertama, berdiskusi dengan kolaborator mengenai metode aplikasi Mind Mapping yang disesuaikan dengan materi tauhid QS. Al Fatihah dan QS. An Naas. Langkah kedua, membuat RPP dan alat pembelajaran dengan mengintegrasikan indikator pembelajaran metode Mind Mapping. Langkah ketiga, mempersiapkan lembar observasi atau lembar pengamatan. Lembar 
pengamatan dipersiapkan untuk mengamati motivasi peserta didik dan guru, saat melakukan proses pembelajaran. Langkah keempat, merancang desain kelas untuk menghadirkan suasana belajar yang nyaman. Kelas tetap menggunakan ruang kelas sebagai tempat belajar. Setelah mendesain kelas dilanjutkan merancang tes hasil belajar diakhir pembelajaran. Tes digunakan sebagai alat pengukur hasil belajar peserta didik.

Pelaksanaan pembelajaran berdurasi waktu 2X40 menit. Langkahlangkah pembelajaran yang dilakukan adalah: Kegiatan awal : guru mengucapkan salam dan berdoa bersama; guru memeriksa kehadiran, kerapian berpakaian, posisi tempat duduk disesuaikan dengan kegiatan pembelajaran; guru menyampaikan tujuan pembelajaran; guru memotivasi peserta didik tentang pentingnya tauhid; guru bertanya tentang pelajaran yang telah lalu (tauhid QS. Al Fatihah dan QS. An Naas); guru menyampaikan Kompetensi Dasar terkait dengan materi yang akan disampaikan.

Kegiatan Inti: peserta didik mengamati model mind mapping pertemuan sebelumnya; peserta didik membaca materi tauhid QS. Al Falaq dan QS. Al Ikhlas; peserta didik mengamati penjelasan guru melalui gambar/tayangan mind mapping tentang materi tauhid QS. Al Falaq; peserta didik mempersiapkan media/alat bantu pembelajaran (buku tulis/kertas HVS, spidol/pensil warnawarni, pensil, ballpoint, penghapus); peserta didik membaca buku untuk mencari informasi tentang tauhid, yang terdapat dalam QS. Al Falaq dan QS. Al Ikhlas, terjemahannya, kandungan suratnya/penjelasannya; peserta didik mengemukakan hasil pengamatannya dengan membuat mind mapping secara individu di kertas HVS; guru membimbing peserta didik yang mengalami kesulitan dalam membuat mind mapping secara individu; peserta didik dan guru saling mengkomunikasikan dan memberi masukan tentang mind mapping yang telah dibuatnya; peserta didik menjelaskan tentang maksud dari mind mapping yang sudah dibuatnya.

Kegiatan Penutup : peserta didik bersama guru membuat kesimpulan tentang materi pembelajaran yang telah dilakukan; menugaskan peserta didik untuk pertemuan berikutnya, belajar dari mind mapping materi tauhid QS. Al Fatihah sampai QS. Al Ikhlas yang telah dibuatnya; peserta didik diminta melakukan refleksi dengan menjawab pertanyaan -pertanyaan yang diajukan guru;

peserta didik menjawab soal-soal post tes; menutup pelajaran dengan berdoa membaca hamdalah bersama..

Pada pertemuan 2 siklus II guru telah menerapkan metode Mind Mapping. Dibandingkan dengan pertemuan 1 pada siklus 1 , pembelajaran pertemuan 2 siklus II ini peserta didik semakin memahami tugas dan tata cara melaksanakan pembelajaran dengan metode Mind Mapping, sehingga proses pembelajaran tidak banyak menemui kendala.

Adapun langkah penerapan Mind Mapping dalam penelitian yang dilaksanakan adalah : guru menjelaskan tauhid QS. Al Falaq dengan metode 
mind mapping; peserta didik membaca materi tauhid QS. Al Ikhlas, terjemahan, dan isi kandungannya; peserta didik membuat mind mapping tauhid QS. Al Ikhlas secara individu dengan menggunakan kertas dan pensil warna yang sudah disiapkan. Ini yang membedakan siklus I dan II, kalau pada siklus I peserta didik membuat mind mapping secara kelompok, kalau pada siklus II ini peserta didik membuat mind mapping secara individu, karena mereka sudah punya pengalaman dan paham bagaimana prosedur dan prinsip-prinsip membuat mind mapping yang sudah dilaksanakan pada siklus I; guru mengontrol proses pembuatan mind mapping satu persatu dan membantu mengarahkan peserta didik yang masih bingung; peserta didik menyelesaikan tugas membuat mind mapping dan menyempurnakannya; meminta salah satu siswa untuk menjelaskan apa yang sudah ditulis dalam mind mapping; peserta didik mengumpulkan hasil mind mapping.

Metode Mind Mapping secara umum sudah diterapkan oleh guru dalam sintaks pembelajaran pada siklus II dengan baik.

Motivasi siswa pada pertemuan 2 siklus II semakin meningkat. Dari hasil wawancara tertulis dengan 30 peserta didik, sebanyak 28 peserta didik merasa bersemangat dan tertarik dengan metode mind mapping, pelajaran Quran Hadis menjadi lebih mudah untuk dipahami dan dimengerti. Rincian selengkapnya dapat dilihat dalam tabel sebagai berikut :
Tabel 3.

Tingkat motivasi peserta didik pertemuan 2 siklus II

\begin{tabular}{|r|l|c|c|}
\hline No & $\begin{array}{l}\text { Predikat } \\
\text { motivasi }\end{array}$ & Jumlah & Prosentase \\
\hline 1 & sangat baik & 0 & $0.00 \%$ \\
\hline 2 & Baik & 28 & $93,33 \%$ \\
\hline 3 & Sedang & 2 & $06,66 \%$ \\
\hline 4 & Buruk & 0 & $0.00 \%$ \\
\hline 5 & sangat buruk & 0 & $0.00 \%$ \\
\hline
\end{tabular}

Dari data tersebut diperoleh perubahan tingkat motivasi antara siklus I pertemuan 1 dengan siklus II pertemuan 2. Peserta didik merasa semakin semangat dan senang karena mereka terlibat aktif melaksanakan praktik membuat mind mapping, sehingga kendala yang dihadapi relatif tidak berarti. Hasil belajar siswa pada pertemuan 2 siklus II diperoleh dari post tes materi Tauhid QS. Al Ikhlas. Rincian hasil tes selengkapnya dapat dilihat dalam tabel sebagai berikut:

Tabel 4.

Hasil Belajar siklus II Pertemuan 2 hasil post tes

\begin{tabular}{|l|c|c|c|l|}
\hline No & Kriteria & $\begin{array}{c}\mathrm{Jm} \\
1\end{array}$ & $\%$ & Tingkat \\
\hline 1 & KKM $<$ & 1 & $03,33 \%$ & $\begin{array}{l}\text { Di } \\
\text { bawah } \\
\text { KKM }\end{array}$ \\
\hline 2 & KKM $>$ & 29 & $96,66 \%$ & $\begin{array}{l}\text { Di atas } \\
\text { KKM }\end{array}$ \\
\hline
\end{tabular}

Refleksi dilakukan dalam 4 aspek yakni aspek proses pembelajaran, penerapan metode RPP, motivasi belajar dan hasil belajar. Berdasarkan hasil diskusi dengan kolaborator disimpulkan beberapa hal. Kesimpulan refleksi pertemuan 2 siklus II adalah : pembelajaran mind mapping memerlukan banyak persiapan baik media, sumber dan waktu; perlu meningkatkan penguasaan kelas saat 
pembelajaran sehingga beberapa siswa tetap fokus melakukan hal yang ditugaskan; pengelolaan waktu harus terampil sehingga proses pembelajaran sesuai dengan sintaks yang sudah direncanakan; penerapan metode mind mapping dalam pembelajaran $\mathrm{Al}$ Qur'an Hadis materi Tauhid QS. Al Fatihah, An Naas, Al Falaq, Al Ikhlas sangat tepat meningkatkan hasil belajar dan motivasi peserta didik. Hasil penelitian ini berkaitan dengan meningkatnya motivasi dari pra siklus sampai siklus II dapat dijabarkan dalam bentuk rincian table sebagai berikut:

Tabel 5.

\section{Peningkatan motivasi menurut} jumlah siswa semua siklus

\begin{tabular}{|c|l|c|c|c|c|c|}
\hline \multirow{2}{*}{ No } & \multirow{2}{*}{ Tahap } & \multicolumn{5}{|c|}{$\begin{array}{c}\text { Tingkat motivasi menurut } \\
\text { jumlah peserta didik }\end{array}$} \\
\cline { 3 - 7 } & & SB & B & S & K & SK \\
\hline 1 & $\begin{array}{l}\text { Siklus 1 } \\
\text { Pertemuan } \\
1\end{array}$ & 0 & 20 & 10 & 0 & 0 \\
\hline 2 & $\begin{array}{l}\text { Siklus 1I } \\
\text { Pertemuan } \\
2\end{array}$ & 0 & 28 & 2 & 0 & 0 \\
\hline
\end{tabular}

Dari tabel di atas, motivasi belajar siswa dengan penerapan metode mind mapping dalam pembelajaran materi materi Tauhid QS. Al Fatihah, QS. An Naas, QS. Al Falaq, QS. Al Ikhlas selalu meningkat dalam setiap tahap. Berkaitan dengan hasil belajarnya pun, peserta didik kelas VIIA juga mengalami peningkatan. Apabila dijabarkan dalam sebuah tabel adalah sebagai berikut:

Tabel 6.

\section{Peningkatan Hasil Belajar peserta didik dalam semua tahap/siklus}

\begin{tabular}{|c|c|c|c|}
\hline No & Tahap & \multicolumn{2}{|c|}{$\begin{array}{c}\text { Prosentase Hasil Belajar } \\
\text { Peserta Didik }\end{array}$} \\
\hline & & Tuntas & Tidak Tuntas \\
\hline
\end{tabular}

\begin{tabular}{|l|l|l|l|}
\hline 1 & Pra Siklus & $16,66 \%$ & $83,33 \%$ \\
\hline 2 & Siklus I & $86,66 \%$ & $13,33 \%$ \\
\hline 3 & Siklus II & $96,66 \%$ & $03,33 \%$ \\
\hline
\end{tabular}

Peningkatan hasil belajar peserta didik dan motivasi pada setiap tahap dipengaruhi dari penggunaan metode Mind Mapping dalam pembelajaran Al Qur'an Hadis materi Tauhid QS. Al Fatihah, QS. An Naas, QS. Al Falaq, QS. Al Ikhlas.

\section{E. SIMPULAN}

Berdasarkan data dan analisis penelitian dari bab I sampai bab IV mengenai peningkatan motivasi dan hasil belajar siswa pada materi Tauhid QS. Al Fatihah, QS. An Naas, QS. Al Falaq, QS. Al Ikhlas. melalui metode Mind Mapping pada peserta didik kelas VIIA semester gasal tahun pelajaran 2019/2020 di MTs Negeri 4 Bantul, diperoleh kesimpulan sebagai berikut: Penggunaan metode Mind Mapping dapat meningkatkan motivasi dan hasil belajar materi Tauhid QS. Al Fatihah, QS. An Naas, QS. Al Falaq, QS. Al Ikhlas. pada peserta didik kelas VIIA semester gasal MTs Negeri 4 Bantul tahun pelajaran 2019/2020; peran metode Mind Mapping dalam meningkatkan motivasi dan hasil belajar materi Tauhid QS. Al Fatihah, QS. An Naas, QS. Al Falaq, QS. Al Ikhlas dapat dilihat dari perolehan persentase masing masing siklus. Prosentase motivasi belajar siswa pada siklus I pertemuan 1 sebesar $66,66 \%$, siklus II pertemuan 2 naik menjadi 93,33\%. Prosentase hasil belajar siswa pada pra siklus $16,66 \%$ yang tuntas. Pada siklus I naik menjadi $86,66 \%$ dan siklus II naik lagi 1menjadi 96,66\% yang tuntas. 
Berdasarkan hal tersebut di atas peneliti memberikan saran kepada guru Al Qur'an Hadis hendaknya mempersiapkan dengan baik mengenai materi dan alat ajar yang akan digunakan pada saat pembelajaran, dan meningkatkan kualitas pembelajarandengan cara menggunakan metode dan strategi bervariasi agar peserta didik lebih termotivasi saat belajar. Serta hendaknya guru meningkatkan pengetahuan, kualitas dan profesionalitas, karena guru merupakan sosok yang ditiru dan ladang ilmu bagi peserta didik. Kepada pihak madrasah hendaknya memfasilitasi peserta didik dengan sarana dan prasarana yang mendukung dalam menunjang pembelajaran, agar guru lebih mudah dalam menyampaikan materi pembelajaran dan memberikan kesempatan bagi guru untuk mengikuti pelatihan-pelatihan yang dapat menunjang penggunaan metode pembelajaran.

\section{DAFTAR PUSTAKA}

Aris Shoimin, 68 Model Pembelajaran Inovati dalam Kurikulum 2013, Yogyakarta:Ar-Ruzz Media, 2014.

E. Mulyasa, Menjadi Guru Professional Menciptakan Pembelajaran Kreatif dan Menyenangkan, Bandung: PT. Remaja Rosdakarya, 2011.

Poerwadarminta, W.J.S, Kamus Umum

Bahasa Indonesia, Balai Pustaka, Jakarta, 1991.

Shanaz, Chaterine, Memori Super Melatih Anak Agar Memiliki Daya Ingat Luar Biasa. Jogjakarta: Starbooks, 2010.

Tony Buzan, Buku Pintar Mind Map, Jakarta: Gramedia Pustaka Utama, 2006.

Trianto, Model-Model Pembelajaran Inovatif Berorientasi

Konstruktivistik Konsep, Landasan Teoritis-Praktis Dan Implementasinya, (Jakarta: Prestasi Pustaka, 2011.

Zainal Arifin, Evaluasi Pembelajaran, Bandung; PT Remaja Rosda Karya, 2008. 